\title{
Antioxidant Activity Test Combination Of Cantigi Leaf Extract (Vaccinium varingiaefolium) And Nail Henna Leaf Extract (Lawsonia inermis Linn)
}

\author{
Mokhamad mahroji ${ }^{*}$, Shelly Taurhesia ${ }^{2}$, Dian Ratih Laksmitawati ${ }^{3}$ \\ 1,2,3 Master of Pharmaceutical Sciences, Faculty of Pharmacy, Pancasila University \\ Jl. Raya Lenteng Agung No. 56-80, RT 1/ RW 3, Srengseng Sawah, \\ Jagakarsa 12630, South Jakarta, Indonesia \\ * Corresponding author: \\ Email : ojierasyidi11@gmail.com
}

\begin{abstract}
.
Traditionally, cantigi leaves (Vaccinium varingiaefolium) are used to heal wounds, swelling, burning, pain, ulcers, and function as analgesic, anti-inflammatory and antiinflammatory. inflammation, and treat fine wrinkles . henna leaves (Lawsonia inermis Linn ) which contains glycosides, steroids, phytosterols, saponins, tannins, and flavonoids which are reported to have benefits for treating boils, scabies, headaches, back pain, and can accelerate hair growth. Cantigi leaves and fruit are reported to contain anthocyanin compounds that function as antioxidants. while the antioxidants contained in cantigi leaves are Beta.-mono-olein, Hexadecanoic acid, and methyl ester . The flavonoids contained in henna leaves also have the potential as antioxidants. We are often exposed to oxidation both produced from within the body or from outside such as pollution, cigarette smoke, UV radiation and food. Antioxidants will neutralize these free radicals so they do not have the ability to steal electrons from cells and DNA. Cantigi leaves and henna leaves were macerated by kinetic maceration method with $70 \%$ ethanol as solvent. Antioxidants were measured using the DPPH method, the single extract of cantigi gave an IC 50 value of $119.23 \pm 4.41 \mu \mathrm{g} / \mathrm{mL}$, while the extract of a single nail henna gave an IC 50 value of $38.38 \pm \mu \mathrm{g} / \mathrm{mL}$. The combination of cantigi leaf extract and nail henna leaf extract with a ratio of $1: 1 ; 2: 1$ and $1: 2$ gave very strong IC50 values, namely $33.84 \mu \mathrm{g} / \mathrm{mL} ; 40.40 \mu \mathrm{g} / \mathrm{mL}$ and $29.85 \mu \mathrm{g} / \mathrm{mL}$, respectively. It was concluded that the combination of cantigi leaf extract and nail henna leaf extract with a ratio of 1:2 gave the best IC50 value of $29.85 \mu \mathrm{g} / \mathrm{mL}$.

Keywords : Vaccinium varingiaefolium; Lawsonia inermis Linn; Antioxidant; DPPH
\end{abstract}

\section{INTRODUCTION}

Free radicals in the body can cause degenerative diseases and premature aging. Free radicals are formed due to the presence of oxidants either from within the body itself or from outside such as environmental conditions where pollution, cigarette smoke, UV rays, and food. Antioxidants are needed to prevent cell or DNA damage caused by free radicals. To maintain antioxidant activity, it is necessary to use a combination of antioxidants. As can be explained in the example of vitamin $\mathrm{C}$ which is able to maintain the activity of vitamin $\mathrm{E}$ as an antioxidant by regenerating tocopherol from tocoperoxyl radicals. Vitamin $\mathrm{E}$ which is a very strong antioxidant will bind to free radicals, then turn into inactive tocoperoxyl radicals . Previous research concluded that Vitamins $\mathrm{C}$ and $\mathrm{E}$ will not work optimally against antioxidants.

Vitamins $\mathrm{C}$ maintains the amount of vitamin $\mathrm{E}$ in cells by reforming vitamin $\mathrm{E}$ radicals to a reduced form and vitamin E inhibits macromolecular and DNA damage caused by oxidation of vitamin C.

(1) Indonesia is rich in natural resources, including biological natural resources. Chemical compounds in plants such as anthocyanins, flavonoids, and polyphenol groups are reported to have antioxidant activity, including cantigi leaves ( Vaccinium varingiaefolium ) (12) and henna leaves ( Lawsonia inermis Linn ). (3) Christian (2021) research on the antioxidant power of $96 \%$ ethanol extract of cantigi leaves using the DPPH method obtained an IC50 value of $16.84 \mu \mathrm{g} / \mathrm{mL}$ (2), while Husni (2018) investigated the antioxidant power of $70 \%$ ethanol extract of henna leaves using the FRAP method, obtained an antioxidant power of $2.82 \mathrm{mmol} \mathrm{Fe}$ (II) $/ 100 \mathrm{~g}$ (3). For this reason, in this study, the antioxidant activity of the single extract of cantigi leaves and the single extract of henna nails leaves will be measured using the DPPH method. The IC50 values obtained from each extract will be compared against the combination of 
cantigi leaf extract and nail henna leaf extract. The ratio of the combination of cantigi leaf extract and henna leaf extract used was 1:1;1:2 and 2:1. Antioxidant activity can be further classified into very strong, strong, moderate and weak as shown in Table 1 below.

Table 1. Classification of the strength of antioxidant activity (5)

\begin{tabular}{|l|l|}
\hline $\begin{array}{l}\text { Concentration } \\
\mathrm{IC}_{50}(\mu \mathrm{g} / \mathrm{mL})\end{array}$ & $\begin{array}{c}\text { Activity classification } \\
\text { Antioxidant }\end{array}$ \\
\hline$<50$ & Very strong \\
\hline $50-100$ & Strong \\
\hline $100-250$ & Currently \\
\hline $250-500$ & Weak \\
\hline$>500$ & Not active \\
\hline
\end{tabular}

\section{METHODS}

This study used an experimental method in selecting a combination of cantigi leaf extract ( Vaccinium varingiaefolium ) and nail henna leaf extract ( Lawsonia inermis Linn ) which has very strong antioxidant power, as indicated by the best IC50 value of a ratio of $1: 1 ; 2: 1$ and 1:2.

\section{Place and time of research}

The research was conducted at the Faculty of Pharmacy, Pancasila University and UPTD. PPMHP Banten Province. The research period starts from June 2021 to December 2021, with letter number 523/PPMHP-046.A/V/2021.

\section{Research Sample}

The materials used in this study were cantigi leaves obtained from Mount Papandayan, Garut Regency and henna leaves obtained from Padarincang Serang Regency.

\section{Research Tools}

Analytical Balance, Homogenizer, maceration apparatus, rotary evaporator, Uv-Vis Spectrophotometer, $\mathrm{pH}-$ meter, Brookfield Viscometer, Memmert Oven, pyrex test tube, test tube rack .

\section{Extract Making}

Using the kinetic maceration method, with $70 \%$ ethanol as solvent and the extraction was carried out several times. Then the extract was concentrated with an evaporator at a temperature of $400 \mathrm{C}$ and a thick extract was obtained. (8)

\section{Quality Test of cantigi leaf extract (CLE) and nail henna leaf extract (NHLE)}

After obtaining a thick extract, a quality test is carried out, which includes:

- Specific parameters (organoleptic, water soluble extract content, ethanol soluble extract content) $(5,6)$

- Non-specific parameters (drying shrinkage determination of moisture content, determination of total ash content, acid insoluble ash content, determination of residual solvent) $(5,6)$

- Test for microbial and heavy metal contamination (7).

- Photochemical screening of each extract was carried out to see the secondary metabolites contained in each extract $(15,10)$.

\section{Antioxidant Activity Test by DPPH method}

Weighed a number of single thick extracts of cantigi leaves and extracts of henna nails leaves and dissolved in methanol p.a to obtain a concentration of $1000 \mu \mathrm{g} / \mathrm{mL}$, for CLE a concentration series of 0 was made; $10.47 ; 20.94 ; 41.88 ; 83.75$; and 167.50 , as well as for NHLE $0 ; 4.28 ; 8.56 ; 17.13 ; 34.25$ and 68.50 then for the combined extract, a number of thick extracts of cantigi leaves were weighed and the extract of henna nails was added in a ratio of 1:1; 1:2 and 2:1, and homogenize. The combination of these extracts was dissolved in methanol p.a until a concentration of $1000 \mu \mathrm{g} / \mathrm{mL}$ was obtained, from which a series of concentrations was made from $0 ; 3.13 ; 6.25 ; 12.50 ; 25$ and $50 \mu \mathrm{g} / \mathrm{mL}$. A total of $2 \mathrm{~mL}$ of each test solution was added $2 \mathrm{~mL}$ of $0.002 \%$ DPPH. homogenized then incubated at room temperature for 30 minutes, measure the absorbance at a wavelength of $515 \mathrm{~nm}$ with a UV-Vis spectrophotometer. (11). 
III. RESULTS AND DISCUSSION

\section{Extract Making}

The yield of CLE and NHLE from kinetic maceration using 70\% ethanol solvent which was thenconcentrated with a rotary evaporator were $25.60 \%$ and $28.01 \%$, respectively. As shown in Table 2

Table 2. Extraction Results and Yield Results

\begin{tabular}{cccccc}
\hline Sample & $\begin{array}{c}\text { Simplicity } \\
\text { (g) }\end{array}$ & $\begin{array}{c}\text { Solvent } \\
(\%)\end{array}$ & $\begin{array}{c}\text { Thick } \\
\text { Extract (g) }\end{array}$ & $\begin{array}{c}\text { DER- native } \\
(\%)\end{array}$ & Yield (\%) \\
\hline $\begin{array}{c}\text { Cantigi Leaf } \\
\text { Extract (CLE) }\end{array}$ & 281.6 & $\begin{array}{c}\text { Ethanol } \\
70 \%\end{array}$ & 72.1 & 3,906 & 25,60 \\
\hline $\begin{array}{c}\text { Nail Girlfriend } \\
\text { Leaf Extract } \\
\text { (NHLE) }\end{array}$ & 534 & $\begin{array}{c}\text { Ethanol } \\
70 \%\end{array}$ & 149.6 & 3,570 & 28.01 \\
\hline
\end{tabular}

\section{Quality Test of Cantigi Leaf Extract and Nail Henna Leaf Extract}

The results of the quality test of the two extracts can be seen in Tables 3, 4, 5 and 6 , indicating that the specific and non-specific parameters met the requirements. And the results of the microbial and heavy metal contamination tests also meet the requirements in accordance with the 2017 FHI regulations $(6,7)$

Table 3. Specific Parameter Quality Test Results

\begin{tabular}{|c|c|c|c|}
\hline Specific parameters & $\begin{array}{l}\text { Cantigi leaf extract } \\
\text { (CLE) }\end{array}$ & & $\begin{array}{l}\text { Nail henna leaf extract } \\
\text { (NHLE) }\end{array}$ \\
\hline \multicolumn{4}{|c|}{ Organoleptic } \\
\hline Shape & Thick & & Thick \\
\hline Color & Dark Chocolate & & Dark Chocolate \\
\hline Smell & Special Extract & & Special Extract \\
\hline Water soluble juice content & $81.40 \%$ & & $58.49 \%$ \\
\hline $\begin{array}{c}\text { Ethanol soluble extract } \\
\text { content }\end{array}$ & $12.47 \%$ & & $12.58 \%$ \\
\hline \multicolumn{4}{|c|}{ Table 4. Non-specific parameter quality test results } \\
\hline Non-specific parameters & CLE & NHLE & $\begin{array}{c}\text { Condition } \\
\text { (Depkes RI 2017) }\end{array}$ \\
\hline Drying shrink & $10.07 \%$ & $13.0 \%$ & $\geq 10 \%$ \\
\hline Water content & $5.41 \%$ & $5.71 \%$ & $\leq 10 \%$ \\
\hline Total ash content & $6,41 \%$ & $2,91 \%$ & $\leq 10 \%$ \\
\hline Acid insoluble ash content & $0,36 \%$ & $0,82 \%$ & $\leq 10 \%$ \\
\hline Residual solvent & Not detected & $0,2 \%$ & $\leq 1 \%$ \\
\hline
\end{tabular}

Table 5. Results of determination of microbial contamination

\begin{tabular}{cccc}
\hline $\begin{array}{c}\text { Parameters of Microbial } \\
\text { Contamination }\end{array}$ & CLE & NHLE & $\begin{array}{c}\text { Condition } \\
\text { (BPOM RI 2014) }\end{array}$ \\
\hline ALT & $<10 \mathrm{cfu} / \mathrm{g}$ & $<10 \mathrm{cfu} / \mathrm{g}$ & $10^{6} \mathrm{cfu} / \mathrm{g}$ \\
\hline $\mathrm{AKK}$ & $<10 \mathrm{cfu} / \mathrm{g}$ & $<10 \mathrm{cfu} / \mathrm{g}$ & $10^{4} \mathrm{cfu} / \mathrm{g}$ \\
\hline
\end{tabular}

Table 6. Results of determination of metal contamination

\begin{tabular}{cccc}
\hline Metal Contamination Parameter & $\begin{array}{c}\text { CLE } \\
\mathrm{mg} / \mathrm{kg}\end{array}$ & $\begin{array}{c}\mathrm{NHLE} \\
\mathrm{mg} / \mathrm{kg}\end{array}$ & $\begin{array}{c}\text { Condition } \\
\text { (BPOM RI 2014) }\end{array}$ \\
\hline Mercury $(\mathrm{Hg})$ & 0.0002 & 0.0001 & $1 \mathrm{mg} / \mathrm{kg}$ \\
\hline Lead $(\mathrm{Pb})$ & 0.0019 & Not detected & $20 \mathrm{mg} / \mathrm{kg}$ \\
\hline Cadmium $(\mathrm{Cd})$ & 0.0017 & 0.0017 & $5 \mathrm{mg} / \mathrm{kg}$ \\
\hline Manganese $(\mathrm{Mn})$ & 0.7329 & 0.7258 & $5 \mathrm{mg} / \mathrm{kg}$ \\
\hline
\end{tabular}


Table 7. Results of phytochemical screening analysis

\begin{tabular}{|c|c|c|c|c|}
\hline Test Parameters & Reactor & Observation & $\begin{array}{l}\text { Results } \\
\text { CLE }\end{array}$ & $\begin{array}{l}\text { Results } \\
\text { NHLE }\end{array}$ \\
\hline Alkaloids & $\begin{array}{c}\text { Chloroform, }+\mathrm{H}_{2} \mathrm{SO}_{4} \text { Mayer } \\
\text { Dragendroff }\end{array}$ & $\begin{array}{l}\text { White precipitate } \\
\text { Yellow precipitate }\end{array}$ & + & + \\
\hline & & & + & + \\
\hline Flavonoids & Powder $\mathrm{Mg}+\mathrm{H}_{2} \mathrm{O}+\mathrm{HCl}$ & Yellow orange & + & + \\
\hline Saponins & $\mathrm{H}_{2} \mathrm{O}+\mathrm{HCl}$ & Embossed foam & + & + \\
\hline Tannins & $\mathrm{H}_{2} \mathrm{O}+\mathrm{FeCl}_{3}$ & Greenish black & + & + \\
\hline Steroids/Triterpenoids & $\mathrm{CH} 3 \mathrm{COOH}+\mathrm{H} 2 \mathrm{SO} 4$ & greenish & $\begin{array}{l}\text { + Steroids / } \\
\text { - Triterpenoids }\end{array}$ & $\begin{array}{c}\text { - Steroids / } \\
\text { - Triterpenoids }\end{array}$ \\
\hline
\end{tabular}

Phytochemical screening aims to provide an overview of the initial group of compounds found in the studied plants $(15,10)$. The phytochemical screening from CLE showed positive results for secondary metabolites of alkaloids, flavonoids, saponins, tannins, steroids and phenols. While NHLE showed positive results for secondary metabolites of alkaloids, flavonoids, saponins, tannins and phenols.

Antioxidant Test using the DPPH. method

Ascorbic acid is a raw material for comparison with the category of having very strong antioxidant activity. The IC 50 value is an indicator of the interpretation of the test results of antioxidant activity using the DPPH method. (14) Ascorbic acid has a polyhydroxy group that will increase antioxidant activity. (4) The results of the duplo measurement for antioxidants with DPPH obtained the IC 50 value of ascorbic acid of $1.81 \pm 0.02 \mathrm{~g} / \mathrm{mL}$ as shown in graph 1 , which shows a very strong antioxidant power.

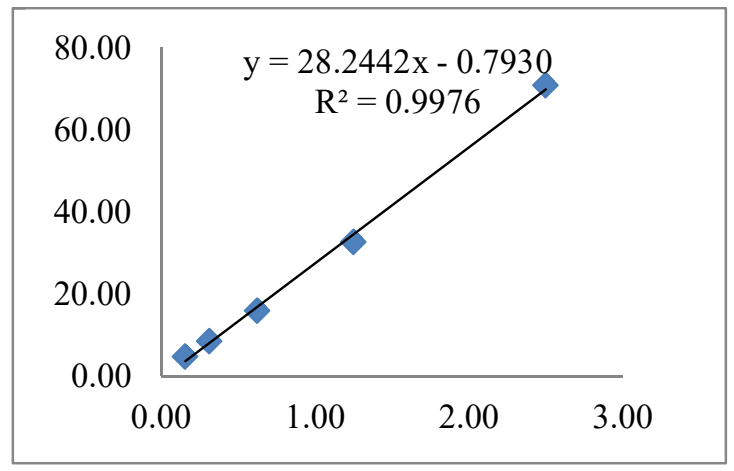

Fig 1. Measurement of antioxidant ascorbic acid using DPPH

Ascorbic acid is a raw material for comparison with the category of having very strong antioxidant activity. The IC 50 value is an indicator of the interpretation of the test results of antioxidant activity using the DPPH method. (14) Ascorbic acid has a polyhydroxy group that will increase antioxidant activity. (4)

Table 8. Antioxidant Test Results Single Extract of Cantigi Leaves

\begin{tabular}{lllll}
\hline \multirow{2}{*}{$\begin{array}{l}\text { Concentration } \\
(\mathbf{g} / \mathbf{m L})\end{array}$} & \multicolumn{2}{l}{$\mathbf{1 . \text { measurement }}$} & \multicolumn{2}{l}{ 2.measurement } \\
\cline { 2 - 5 } & $\mathbf{A b s o r b a n c e}$ & \% inhibition & $\begin{array}{l}\text { Absorbance } \\
\mathbf{5 1 5}\end{array}$ & \% inhibition \\
\cline { 2 - 5 } Blank & 0.2556 & & 0.2556 & \\
\hline 10.47 & 0.2551 & 0.20 & 0.2508 & 1.88 \\
\hline 20.94 & 0.2333 & 8.72 & 0.2333 & 8.72 \\
\hline 41.88 & 0.1941 & 24.06 & 0.1942 & 24.02 \\
\hline 83.75 & 0.1570 & 38.58 & 0.1454 & 43.11 \\
\hline 167.50 & 0.0775 & 69.68 & 0.0775 & 69.68 \\
\hline IC50 value & $\mathbf{1 1 6 . 1 1}$ & & $\mathbf{1 2 2 . 3 4}$ & \\
\hline
\end{tabular}

From the analysis results obtained IC50 levels of ascorbic acid are $1.81 \pm 0.02 \mathrm{~g} / \mathrm{mL}$, this shows a very strong interpretation of the results, as shown in graph 1 . Table 8 shows the antioxidant activity test of a single extract of cantigi leaves obtained IC levels 50 was $119.23 \pm 4.41 \mathrm{~g} / \mathrm{mL}$ which showed moderate 
International Journal of Health and Pharmaceutical

antioxidant activity. Nail henna leaf extract gave an IC 50 value of $38.38 \pm 1.67 \mathrm{~g} / \mathrm{mL}$, which is a very strong antioxidant, as shown in Table 9.

Table 9. Antioxidant Test Results Singel Extract of Nail Henna Leaf

\begin{tabular}{ccccc}
\hline \multirow{2}{*}{$\begin{array}{c}\text { Concentration } \\
(\mathbf{g} / \mathbf{m L})\end{array}$} & Absorbance & $\begin{array}{c}\text { \% } \\
\text { inhibition }\end{array}$ & $\begin{array}{c}\text { Absorbance } \\
\mathbf{5 1 5}\end{array}$ & \% inhibition \\
\cline { 2 - 4 } & $\mathbf{5 1 5}$ & & 0.2834 & \\
\hline Blank & 0.2956 & 8.69 & 0.2727 & 3.78 \\
\hline 4.28 & 0.2699 & 14.92 & 0.2541 & 10.34 \\
\hline 8.56 & 0.2515 & 26.89 & 0.2184 & 22.94 \\
\hline 17.13 & 0.2161 & 47.60 & 0.1543 & 45.55 \\
\hline 34.25 & 0.1549 & 80.07 & 0.0559 & 80.28 \\
\hline 68.50 & 0.0589 & & 37.20 & \\
\hline IC50 value & 39.55 & &
\end{tabular}

The IC50 value of the combined antioxidant activity test results of CLE and NHLE with a ratio of $1: 1,2: 1,1: 2$, can be seen in Table 10 .

Table 10. Test Results of Combination Extract Antioxidant Activity

\begin{tabular}{|c|c|c|c|c|}
\hline Sample & Test Repeat & IC Rated 50 & $\begin{array}{c}\mathrm{X} \pm \mathrm{SD} \\
\mathrm{IC} 50(\mu \mathrm{g} / \mathrm{mL})\end{array}$ & Interpretation \\
\hline 1CLE:1NHLE & $\begin{array}{l}1 \\
2\end{array}$ & $\begin{array}{l}33.91 \\
33.76\end{array}$ & $33.84 \pm 0.10$ & Very strong \\
\hline 2CLE:1NHLE & $\begin{array}{l}1 \\
2\end{array}$ & $\begin{array}{l}40.02 \\
40.78\end{array}$ & $40,40 \pm 0.54$ & Very strong \\
\hline 1CLE:2NHLE & $\begin{array}{l}1 \\
2\end{array}$ & $\begin{array}{l}31.45 \\
28.24\end{array}$ & $29.85 \pm 2.27$ & Very strong \\
\hline
\end{tabular}

The three mixtures of CLE and NHLE showed synergistic antioxidant activity, with IC50 values of $33.84 \pm 0.10 \mathrm{~g} / \mathrm{mL}, 40.40 \pm 0.54 \mathrm{~g} / \mathrm{mL}$, and $29.85 \pm 2.27 \mathrm{~g} / \mathrm{ml}$, respectively. -consecutive for $1: 1$ combination ratio; $2: 1$ and 1:2. Initially, a single extract of cantigi leaves only had moderate antioxidant activity. The antioxidant activity of CLE can be increased by combining it with NHLE and provides very strong antioxidant activity.

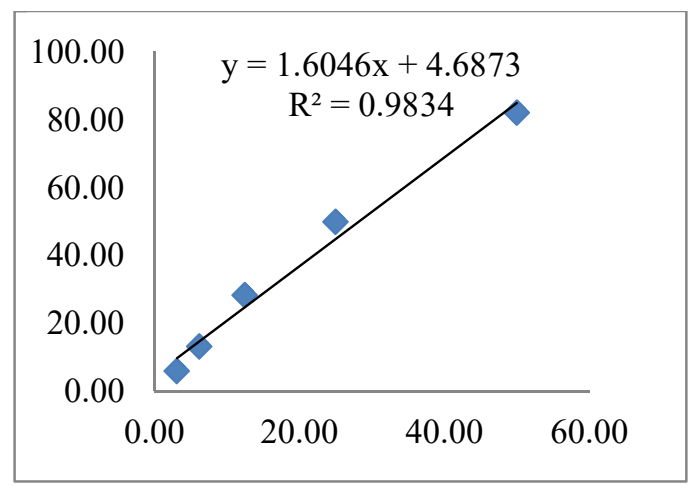

Fig 2. The results of the $1: 2$ combination antioxidant test from CLE and NHLE

Of the three comparisons of the combination of CLE and NHLE, a 2:1 ratio gives the best IC50 value of $29.85 \mathrm{~g} / \mathrm{mL}$ as depicted in graph 2 .

\section{CONCLUSION}

Cantigi leaf extract has moderate antioxidant activity with an IC50 value of $119.23 \pm 4.41 \mu \mathrm{g} / \mathrm{mL}$, nail henna leaf extract has very strong antioxidant activity with an IC50 value of $38.38 \pm 1.67 \mu \mathrm{g} / \mathrm{mL}$. However, the IC50 value of cantigi leaf extract can be increased when combined with henna leaf extract, and the best result is the combination with a 1:2 ratio which provides very strong antioxidant activity with an IC50 value of $29.85 \mu \mathrm{g} / \mathrm{mL}$.. 


\section{ACKNOWLEDGEMENTS}

This research article has been completed, the authors would like to thank the supervisors who have devoted their guidance and direction, and all who have helped in the research.

\section{REFERENCES}

[1] Andre O. Barel, Marc Paye, Howard I. Maibach. Handbook of cosmetic science and technology - 3rd ed. 2009. pages : 301-307

[2] Christian YE, Debora R. Effect of Gelatin and Glutaraldehyde Concentration on Characteristics of Gelatin Nanoparticles Containing Cantigi Extract ( Vaccinium varingiaefolium Miq.) As Antioxidant Effect Of Gelatin And Glutaraldehyde Concentration On Characteristic Of Cantigi (Vaccinium Varingiaefolium Miq.) EXTRACT. 2021:1-7. doi:10.20473/jhpr.vol.4-issue.1.1-7. 3.

[3] Husni E, Suharti N, Pasella A, Atma T, Pharmacy F, Andalas U. Characterization of Simplicia and Leaf Extract of Girlfriend Nails (Lawsonia inermis Linn) and Determination of Total Phenolic Levels and Antioxidant Activity Test. 2018;5(1):12-6.

[4] Konda JP, Siampa JP, Tallei TE, Kepel BJ, Fatimawali F. Antioxidant activity of methanol extracts of Langsat (Lansium domesticum var. pubescens) and Duku (Lansium domesticum var. domesticum) seeds using the DPPH method. J Science. 2020;20(2):113.

[5] Ministry of Health of the Republic of Indonesia A. General Standard Parameters of Medicinal Plant Extracts. Jakarta: Bakti Husada; 2000.

[6] Ministry of Health of the Republic of Indonesia. Indonesian Herbal Pharmacopoeia Edition II . Jakarta.. 2017;213-8.

[7] Regulation of the Head of the Food and Drug Supervisory Agency Number 17 of 2014 concerning Amendments to the Regulation of the Head of BPOM Number HK.03.1.23.07.11.6662 of 2011 concerning Microbial Contamination Requirements And Heavy Metals In Cosmetics. Jakarta.;1-5.

[8] Rizky Amelia F. Determination of Tannin Types and Determination of Tannin Levels from Young Bungur Fruit (Lagerstroemia speciosa Pers.) Spectrophotometrically and Permanganometrically. . J Ilm Mhs Univ Surabaya. 2015;4(2):1.1 0 .

[9] Mailuhu M, Runtuwene MRJ, Koleangan HSJ. Phytochemical Screening and Antioxidant Activity of Soyogik Bark (Saurauia bracteosa DC.) Methanol Extract. ChemProg. 2017;10(1):1-6.

[10] Pukumuang W. Total phenolic contents, antibacterial and antioxidant activities of some Thai medicinal plant extracts. J Med Plants Res. 2012;6(36):4953-60

[11] Sadiyah ER, Kodir RA. Preliminary Study of Anthocyanin Content in Purple Cantigi Fruit (V accinium V aringiaefolium (BL.) MIQ.) Y Which Functions As An Antioxidant Supplement. 2012;95-100.

[12] Sari AK, Ayati R. Determination of Antioxidant Activity of Ethanol Extract of Kaffir lime Leaf (Citrus hystrix D. C ) by DPPH method (1,1-diphenyl-2-picrylhydrazyl). J Curr Pharm Sci. 2018;1(2):69-74.

[13] Sari DM, Anwar E, Nurjanah, Arifianti AE. Antioxidant and tyrosinase inhibitor activities of ethanol extracts of brown seaweed (Turbinaria conoides) as lightening ingredient. Pharmacogn J. 2019;11(2):379-82.

[14] Simare E. Phytochemical Screening Ethanol Extract of Itchy Leaves (Laportea decumana (Roxb.) Wedd). Pharmacy. 2014;11(01):undefined. 